\title{
ОЦЕНКА ПЕРСПЕКТИВНОСТИ СЕКТОРА УМНОЙ ОДЕЖДЫ НА ОСНОВАНИИ АНАЛИЗА СТАРТАП-ЛАНДШАФТА
}

(C) 2021 Хэлльстром Денис Александрович

студент-магистр

Университет ИТМО, Россия, Санкт-Петербург

E-mail: dion.hellstrom@yandex.ru

(c) 2021 Хэлльстром Анастасия Константиновна

студент-магистр

Университет ИТМО, Россия, Санкт-Петербург

E-mail: nastya_zem@mail.ru

(c) 2021 Пашинцева Виктория Сергеевна

студент-магистр

Университет ИТМО, Россия, Санкт-Петербург

E-mail: victoria.polukhina@mail.ru

\section{(C) 2021 Павлюков Александр Викторович}

студент-магистр

Университет ИТМО, Россия, Санкт-Петербург

E-mail: off.mail.pavlyukov.a.v@gmail.com

\section{(C) 2021 Язев Ярослав Вячеславович}

студент-магистр

Университет ИТМО, Россия, Санкт-Петербург

E-mail: yaroslav.v.yazev@gmail.com

Научная статья посвящена исследовательскому анализу особенностей развития сектора умной одежды на основе анализа стартап-проектов. Актуальность исследования обусловлена увеличением числа стартап-проектов, где предприятия используют информационные технологии и инновации для совершенствования сектора умной одежды. В рамках статьи рассмотрены основные направления сектора умной одежды. Проанализирована роль умной одежды в спортивной индустрии и медицине. Проанализированы перспективы развития сектора умной одежды.

Ключевые слова: сектор умной одежды; умная одежда; стартап; стартап-ландшафт; информационные технологии; инновации; текстиль; индустрия моды.

Сектор умной одежды характеризуется как инновационное направление развития текстильной промышленности, в рамках которой проводится производство умной одежды. Под последним понятием подразумевается одежда, которая может интерактивно взаимодействовать с окружающей средой, воспринимая сигналы, обрабатывая информацию и запуская ответные реакции.

В нашем понимании, сектор умной одежды - это сфера текстильной промышленности, где производится одежда и текстильная продукция, включающая в себя различные информационные технологии, инновации, которые совершенствуют жизнедеятельность человека
Актуальность научного исследования на тематику «оценка перспективности сектора умной одежды на основании анализа стартапландшафта» обусловлена увеличением числа стартап-проектов, где предприятия используют информационные технологии и инновации для совершенствования сектора умной одежды.

По этой причине, целью научной работы выступает проведение исследовательского анализа особенностей развития сектора умной одежды на основе анализа стартап-проектов.

Для этого в рамках исследовательской работы необходимо решение таких задач, как:

- рассмотреть основные направления в секторе умной одежды; 
- проанализировать роль умной одежды в спортивной индустрии и медицине;

- проанализировать перспективы развития сектора умной одежды

Технический прогресс, наблюдаемый в рамках шестого технологического уклада и четвертой промышленной революции касается различных направлений и сфер жизнедеятельности человечества. Среди них и текстильная промышленность, где возникает сектор «умной» одежды, включающий в себя адаптацию и коллаборацию с информационными технологиями [4].

Кусмидиновой М. Х. и Решетниковой Н. С. в рамках научной работы [1] была определена классификация сектора умной одежды на такие направления, как:

1. Умная одежда, как личный доктор, где информационные технологии и различные датчики используются в целях медицинской диагностики носителя одежды.

2. Умная одежда, как носитель информации, где инновации используются в целях уведомления каких-то изменений. Например, партнерство компании индустрии моды Levis и технологического гиганта Google позволило создать курточки нового типа, рукава которых формируют вибрации в целях уведомления носителя одежды об потере смартфона.

3. Умная одежда, как источник комфорта, где инновации используются в целях повышения комфорта носителя одежды. Например, компания Hi-Fin производит перчатки, ткань которой позволяет использовать их при работе с сенсорными экранами, что невозможно с другими обыденными текстильными товарами.

4. Умная одежда, как помощник в спорте, где инновации используются для совершенствования спортивных товаров. Например, компания Li-Ninq произвела спортивные кроссовки, в которые встроенные различные датчики, позволяющие записывать информацию о скорости бега, частоте шагов, длине шагов и т.д.

Наиболее перспективными сектора производства умной одежды выступает спортивная индустрия и медицина. Так, в спортивной индустрии важными становятся следующие моменты:

- красота и внешний вид;

- удобность и комфорт;

- повышение возможностей демонстрации спортивных результатов;

- получение обратной информации и связи для анализа тренировочного цикла.

Умная одежда позволяет мировым брендам спортивной индустрии производить новую текстильную продукцию, которая остается такой же красивой, модной, комфортной, но при этом повышает спортивные возможности клиентов. K тому же, создаются новые продукты умной одежды в спорте, которые позволяют обеспечить защиту важных жизненных функций (например, анализ кардиосистемы спортсмена или ткань, которая защищает от перегрева или переохлаждения) [5].

Сектор медицины - это будущий кладезь для развития умной одежды. На сегодняшний день медицинская отрасль нуждается в производстве новой одежды, которая позволит врачам увеличивать свою эффективность деятельности. Немаловажным направлением применения умной одежды и информационных технологий в медицине является повышение практической роли преждевременной диагностики, которая снижает хронические заболевания и смертность пациентов до 60\% [6].

Актуальным направлением умной одежды в медицине является и лечебная одежда, характеристика которой заключается в том, что сами текстильные изделия пропитаны наночастицами или микрокапсулами, в которых содержится необходимые лекарственные препараты [8].

По нашему мнению, одним из главных факторов дальнейшего развития сектора умной одежды является популяризация технологий искусственного интеллекта.

Использование технологий искусственного интеллекта при развитии сектора умной одежды способно привнести такие преимущества, как:

- улучшение процедуры управления цифровыми данными, информацией, которую формируют другие технологии, внедренные в объект одежды;

- повышение качества обслуживания клиентов, если умная одежда включает в себя данную функцию сопровождения при использовании;

- оптимизация финансовых расходов, благодаря чему стоимость умной одежды может быть снижена.

Вектор развития легкой промышленности сейчас таков, что появление новых решений в разных высокотехнологичных сферах приводит к ускорению динамики роста мирового рынка «умной» одежды. Возможности инновационного 
текстиля, расширяющего общую полезность и функциональные возможности обычных тканей, огромны.

На основе отчета Transparency Market Research можно отметить, что одним из основных драйверов роста сектора «умной одежды» будет продукция носимых устройств. Аналитики прогнозируют, что в ближайшие несколько лет значительно возрастет популярность портативных приборов, фиксирующих важные для здоровья показатели. При этом они будут все чаще использоваться не столько в целях профилактики болезней, сколько в рамках решения задач спортивной деятельности [2].

Также перспективами развития сектора умной одежды является производство специальной одежды со встроенными техническими датчиками, которые будут делать полноценной жизнь для людей с физическими особенностями [3].
Очевидно, что рынок «умной» одежды находится лишь в начале своего развития, но скорость и новые направления определяются уже сейчас. Крупные технологичные компании вроде Samsung, Google, Levi's, Ralph Lauren и Adidas постепенно стали определять тренды этой индустрии [7].

Таким образом, подводя итоги научной работы, можно заключить, что сектор умной одежды крайне новое направление текстильной промышленности, но имеющее высокие перспективы своего развития в будущем. Наиболее приоритетными отраслями применения умной одежды является спортивная индустрия и медицина, где уже сформирован потребительский спрос на данную продукцию. Благодаря постоянному развитию новых технологий и инноваций, сектор умной одежды будет совершенствоваться, что увеличит перспективы его масштабирования в будущем.

\section{Библиографический список}

1. Кусмидинова М.Х., Решетникова Н. С. «Умная одежда» как пример актуальной коллаборации современных информационных технологий и индустрии моды // Каспийский регион: политика, экономика, культура. 2020. № 4 (65).

2. Очень «умная» одежда. Какие инновации внедряет легпром. URL: https://sber.pro/publication/ochen-umnaiaodezhda-kakie-innovatsii-vnedriaet-legprom (дата обращения: 29.08.2021).

3. Артенян Л.С., Комбарова Т. В., Петросова И. А., Андреева Е.Г. Проектирование умной одежды с элементами технических устройств // Актуальные проблемы инклюзии: качество жизни, безбарьерная среда, образование без границ. 2016. С. 117-121.

4. Тальянова А. С. Умная одежда // Интеллектуальные технологии и средства реабилитации и абилитации людей с ограниченными возможностями (ИТСР-2017). II Всероссийская конференция. 2018. С. 55-58.

5. Будеева О.Н., Григорьева З.Р. Применение «умного» текстиля и современных технологий для проектирования спортивной одежды // Альманах мировой науки. 2018. № 3 (23). С. 44-45.

6. Давлетова Р.P., Будеева О.Н., Григорьева З.Р. К вопросу об обеспечении медицинской отрасли «умной» одеждой // Альманах мировой науки. 2018. № 3 (23). С. 64-66.

7. Ларикова М.Д., Пищинская О.В. Анализ рынка «умной» одежды // Инновации и современные технологии в индустрии моды. 2018. С. 106-109.

8. Алкуабева В.С., Алексеев В. А., Артамбаев М., Барышева А. Д. «Умная одежда» // Вестник современных исследований. 2019. № 6.3 (33). С. 57-61. 